\title{
Validation of Stress Corrosion Cracking Model for High Level Radioactive- Waste Packages
}

S. C. Lu, G. M. Gordon, and P. L. Andresen

This article was submitted to the 2004 ASME Pressure Vessels and Piping Conference, San Diego, CA, July 25-29, 2004

\section{May 12, 2004}

Lawrence

Livermore

National

Laboratory 


\section{DISCLAIMER}

This document was prepared as an account of work sponsored by an agency of the United States Government. Neither the United States Government nor the University of California nor any of their employees, makes any warranty, express or implied, or assumes any legal liability or responsibility for the accuracy, completeness, or usefulness of any information, apparatus, product, or process disclosed, or represents that its use would not infringe privately owned rights. Reference herein to any specific commercial product, process, or service by trade name, trademark, manufacturer, or otherwise, does not necessarily constitute or imply its endorsement, recommendation, or favoring by the United States Government or the University of California. The views and opinions of authors expressed herein do not necessarily state or reflect those of the United States Government or the University of California, and shall not be used for advertising or product endorsement purposes.

This is a preprint of a paper intended for publication in a journal or proceedings. Since changes may be made before publication, this preprint is made available with the understanding that it will not be cited or reproduced without the permission of the author.

This report has been reproduced directly from the best available copy.

Available electronically at http://www.doc.gov/bridge

Available for a processing fee to U.S. Department of Energy

And its contractors in paper from

U.S. Department of Energy

Office of Scientific and Technical Information

P.O. Box 62

Oak Ridge, TN 37831-0062

Telephone: (865) 576-8401

Facsimile: (865) 576-5728

E-mail: reports@adonis.osti.gov

Available for the sale to the public from

U.S. Department of Commerce

National Technical Information Service

5285 Port Royal Road

Springfield, VA 22161

Telephone: (800) 553-6847

Facsimile: (703) 605-6900

E-mail: orders@ntis.fedworld.gov

Online ordering: http://www.ntis.gov/ordering.htm

OR

Lawrence Livermore National Laboratory

Technical Information Department's Digital Library

http://www.llnl.gov/tid/Library.html 


\title{
VALIDATION OF STRESS CORROSION CRACKING MODEL FOR HIGH LEVEL RADIOACTIVE-WASTE PACKAGES
}

\author{
S.C. Lu \\ Lawrence Livermore National Laboratory \\ P.O. Box 808, Livermore, CA USA 94550 \\ e-mail: lu1@IInl.gov
}

\author{
G.M. Gordon \\ AREVA (Framatome ANP) \\ 1180 Town Center DR, Las Vegas, NV USA 89144 \\ e-mail: gerald_gordon@notes.ymp.gov
}

\author{
P.L. Andresen \\ GE Global Research \\ One Research Circle \\ Schenectady, NY USA 12309 \\ e-mail: andresen@crd.ge.com
}

\begin{abstract}
A stress corrosion cracking (SCC) model has been adapted for performance prediction of high level radioactive-waste packages to be emplaced in the proposed Yucca Mountain radioactive-waste repository. SCC is one form of environmentally assisted cracking resulting from the presence of three factors: metallurgical susceptibility, critical environment, and tensile stresses. For waste packages of the proposed Yucca Mountain repository, the outer barrier material is the highly corrosion-resistant Alloy UNS-N06022, the environment is represented by the water film present on the surface of the waste package from dripping or deliquescence of soluble salts present in any surface deposits, and the stress is principally the weld induced residual stress. SCC has historically been separated into "initiation" and "propagation" phases. Initiation of SCC will not occur on a smooth surface if the surface stress is below a threshold value defined as the threshold stress. Cracks can also initiate at and propagate from flaws (or defects) resulting from manufacturing processes (such as welding). To account for crack propagation, the slip dissolution/film rupture (SDFR) model is adopted to provide mathematical formulae for prediction of the crack growth rate. Once the crack growth rate at an initiated SCC is determined, it can be used by the performance assessment (not in the scope of this paper) to determine the time to through-wall penetration for the waste package. This paper presents the development and validation of the SDFR crack growth rate model based on technical information in the literature as well as experimentally
\end{abstract}

determined crack growth rates developed specifically for Alloy UNS N06022 in environments relevant to high level radioactive-waste packages of the proposed Yucca Mountain radioactive-waste repository.

\section{INTRODUCTION}

Radioactive materials such as spent nuclear fuel and highlevel radioactive waste produced by commercial electric power generation, nuclear weapons production, and research and development activities have accumulated since the mid-1940s at sites managed by the U.S. Department of Energy (DOE) and at commercial power generation reactors and storage facilities. The responsible management and disposal of these materials is a critical part of the DOE mission to meet its obligation to dispose of high-level radioactive waste and spent nuclear fuel. Congress in 1987 directed the DOE to investigate Yucca Mountain, Nevada, exclusively, to determine whether it is a suitable site for the first geologic repository for the nation's spent nuclear fuel and high-level radioactive waste.

The engineered barrier system for the Yucca Mountain high level radioactive-waste repository is designed to complement the natural barriers in isolating waste from the environment. The heart of the engineered barrier system is the waste package (WP). According to DOE (2001), typical waste packages (see Fig. 1) would have a dual-metal design containing two concentric cylinders. The inner cylinder would be made of Type 316 Stainless Steel. The outer cylinder would be made of a corrosion-resistant, nickel-based alloy (UNS-N06022). Alloy UNS N06022 would protect the stainless steel inner cylinder 
from corrosion, and Type 316 stainless steel would provide structural support for the thinner Alloy UNS-N06022 cylinder.

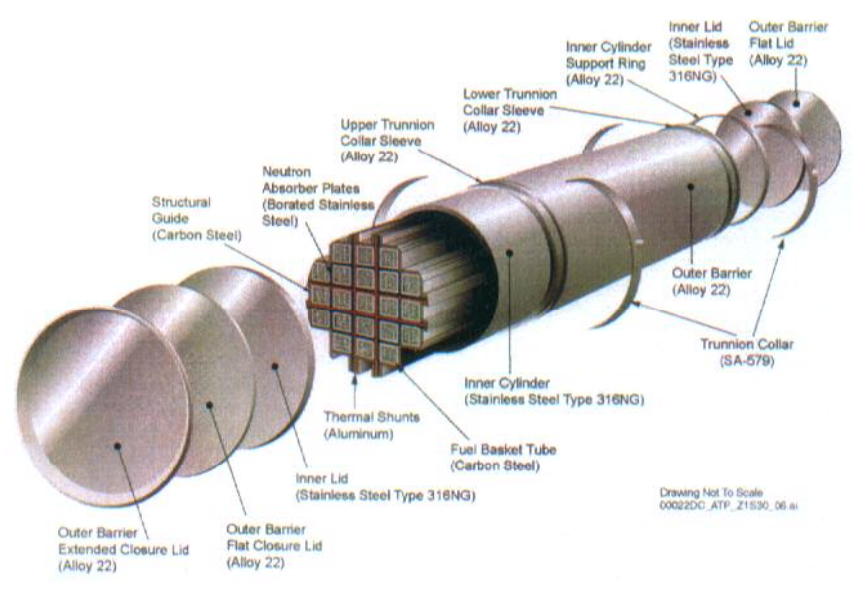

Fig. 1. Typical Waste Package Used for Yucca Mountain Repository.

Each waste package would have outer and inner lids at each end of the cylinder. The outer (closure) lids would be made of Alloy UNS-N06022. The inner lids would be made of Type 316 Stainless Steel. The loading end of the waste package has a third flat closure lid made of Alloy UNS-N06022, which would be placed between the inner lid of stainless steel and the outer lid of Alloy UNS-N06022. The flat closure lid provides an extra barrier against a potential release caused by one form or another environmentally assisted corrosions, such as the stress corrosion cracking (SCC) in waste packages.

SCC is the initiation and propagation of cracks due to three factors, which must be present simultaneously: metallurgical susceptibility, critical environment, and static (or sustained) tensile stresses. The discussion on SCC in this paper will be restricted to the Alloy UNS-N06022 waste package outer barrier (WPOB). The stainless steel structural material is not modeled since the waste package performance assessment does not take corrosion-resistance credit from the stainless steel inner barrier of the WP. The stress that contributes SCC in waste packages is primarily the residual stress induced by the welding processes. The entire waste package will be heat treated (annealed) to basically eliminate the weld residual stress before the loading of waste contents and welding of the closure lids at the loading end. Therefore, the only areas of SCC concern are the closure welds of the waste package at the loading end since they are not heat treated. The treatment of SCC described in this paper is illustrated by the flow diagram shown in Fig. 2.

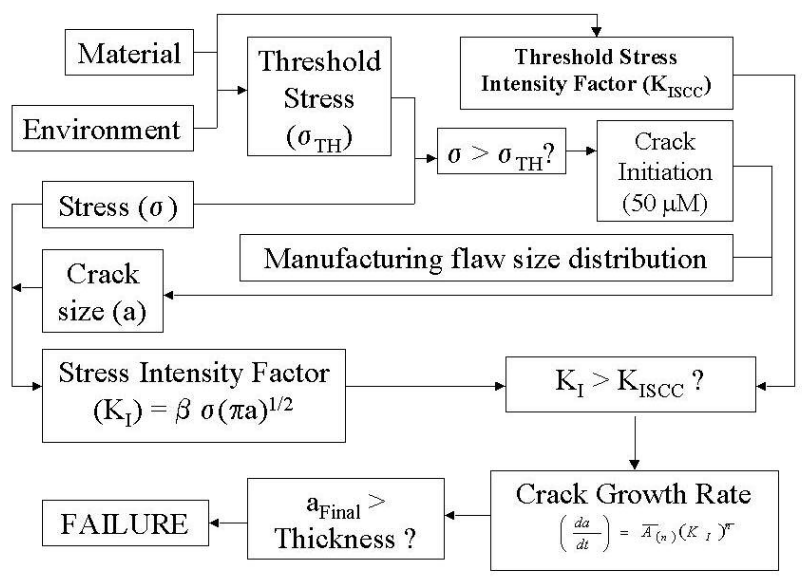
Fig. 2. Flow Diagram for Treatment of Stress Corrosion
Cracking.

\section{CRACK INITIATION}

SCC has historically been separated into "initiation" and "propagation" phases (Jones and Ricker 1987). For the purpose of lifetime modeling, it is appropriate to associate initiation with microscopic crack formation at localized corrosion or mechanical defect sites. In the area of environmentally assisted cracking (such as SCC), coalescence of microscopically small cracks will take place and develop into deeper cracks. Andresen and Ford (1988) used a crack size of $0.05 \mathrm{~mm}(50 \mu \mathrm{m})$ as an equivalent defect from which to start propagating SCC cracks.

For a given alloy, microstructure and environmental conditions - and in the absence of cyclic stresses - initiation of SCC will not occur on a 'smooth surface' (without sharp defects such as weld defects that can generate a significant stress intensity factor) if the surface stress is below a threshold value defined as the threshold stress (ASM International 1987). Recently obtained SCC crack initiation measurements under constant load conditions reported in Young et al. (2003) are summarized in Fig. 3, where the measurements of crack initiation stress are presented as applied stress ratio (the ratio of applied stress to yield strength) vs. time-to-failure (or total exposure time without failure) for specimens subjected to 14,500 hours of exposure in hot concentrated salt solution $\left(\mathrm{pH}=10.3\right.$ at $\left.105^{\circ} \mathrm{C}\right)$. This solution is known as Basic Saturated Water (BSC 2001), designed to simulate the chemistry of concentrated Yucca Mountain ground water. The test results indicated that Alloy UNS-N06022 exhibits excellent SCC resistance since failure was not observed for any of the 120 Alloy UNS-N06022 specimens covering a variety of metallurgical conditions (including as-welded condition). The applied stress ratios were up to about 2.1 times the yield strength (YS) of the as-received material and up to 2.0 times the yield strength of the welded material. This corresponds to about 89 to $96 \%$ of the ultimate tensile strength (UTS). 


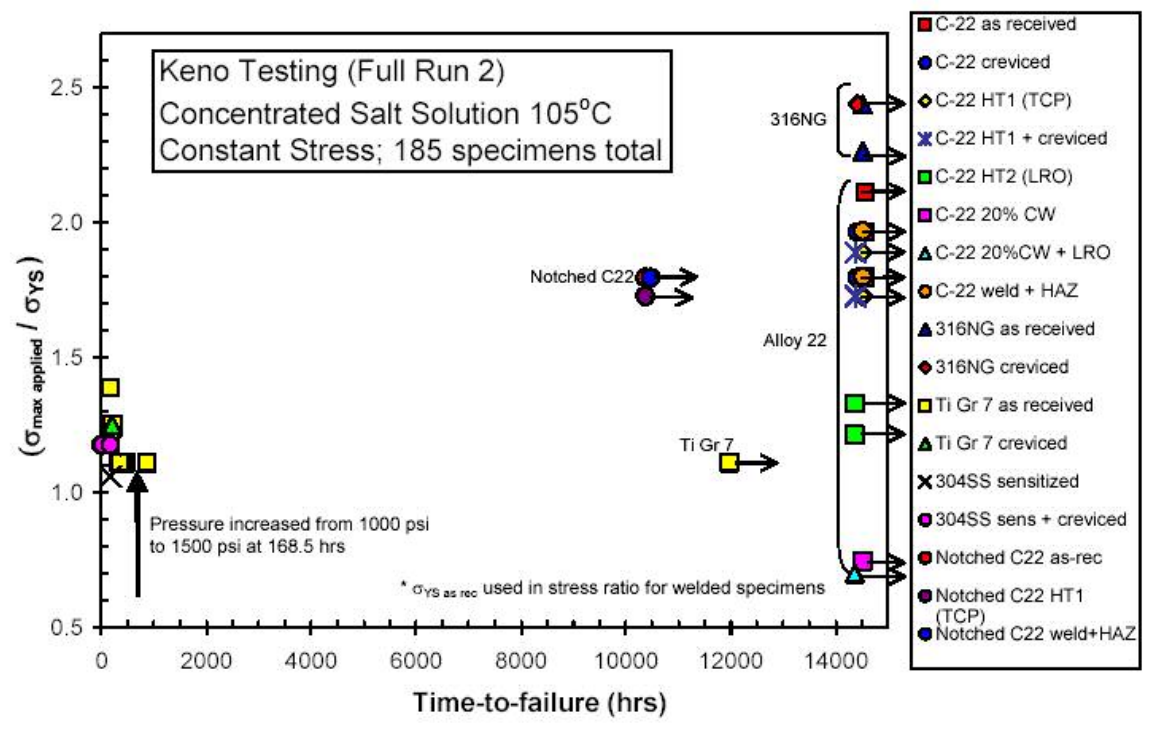

Fig. 3. Failure Stress vs. Time-to-Failure Plot for Crack Initiation Tests.

\section{MANUFACTURING FLAWS}

Initial cracks can also be flaws (or defects) resulting from manufacturing processes (such as welding). The current welding process to be used for the WP final closure weld is the automated Narrow Groove Gas Tungsten Arc Welding (NG-GTAW) process (CRWMS M\&O 1996). The expected type, size and orientation of defects that can result from the GTAW process is supported by a recent weld defect evaluation study in which sixteen full diameter 21 PWR container Alloy UNS N06022 closure weld mockup ring specimens were fabricated using a prototypical cold-wire GTAW process. Weld defects present in these rings were examined by various NDE techniques including liquid penetrant and eddy current surface examinations and volumetric radiographic and ultrasonic (UT) examinations. These were followed by metallographic destructive examination. Information gathered from these weld mockup experiments were used to develop flaw size and density distributions applicable to the closure welds of the WP (BSC 2003).

\section{SLIP DISSOLUTION/FILM RUPTURE MODEL FOR SCC CRACK GROWTH}

As stated earlier in this paper, initiation is associated with microscopic crack formation at localized corrosion or mechanical defect sites. For SCC, coalescence of microscopically small cracks will take place and develop into deeper cracks. Thereafter, the crack may either arrest or continue to propagate. A lifetime crack propagation prediction model can be developed via a fundamental understanding of the cracking mechanism. For the systems of interest, the slip dissolution/film rupture mechanism has been chosen. This cracking mechanism has been successfully applied to model SCC for stainless steel, low-alloy steel, and nickel-based alloys in light water reactor environments (Ford and Andresen 1988; Andresen and Ford 1988).

For constant load conditions, the crack growth rate $\mathrm{V}_{\mathrm{t}}$ (in $\mathrm{mm} / \mathrm{s}$ ) is presented by the following equation:

$$
V_{t}=7.8 \times 10^{-2} n^{3.6}\left(4.1 \times 10^{-14}\right)^{n}\left(K_{I}\right)^{4 n}
$$

where $\mathrm{n}$ is the repassivation parameter to be determined experimentally and $\mathrm{K}_{\mathrm{I}}$ is the stress intensity factor in $\mathrm{MPa}(\mathrm{m})^{1 / 2}$. The derivation of Eq. 1 can be found in Lu et al. (2003).

For Alloy UNS-N06022 under constant load condition, the parameter " $\mathrm{n}$ " can be determined from Eq. 1 based on crack growth rates measured at various levels of applied stress intensity factor, $\mathrm{K}_{\mathrm{I}}$. According to Ford and Andresen (1988), $\mathrm{n}=0.54$ for Type 304 stainless steel in $288^{\circ} \mathrm{C}$ water. Much higher "n" value is expected for Alloy UNS-N06022 because it is highly resistant to SCC. Recent SCC crack growth rate measurements from Andresen et al. (2003) have been made available for the quantification of the parameter $\mathrm{n}$ for the SDFR SCC model to be used for Alloy UNS-N06022. The test data were developed from four Alloy UNS-N06022 specimens tested at $110^{\circ} \mathrm{C}$ in a concentrated mixed salt environment. The specimens were subjected to cyclic loading in order to initiate crack growth and then followed by constant loading conditions with various hold times. The set of test data to be used as input 
for establishing the value of $\mathrm{n}$ for Alloy UNS-N06022 are summarized in Table 1. These data were selected based on a minimum hold time of 85,400 seconds (or $\sim 24$ hours) because Eq. 1 is applicable only to constant loading condition. It is unrealistic to determine the parameter $n$ in this equation based on test data at relative short hold times. The only exception is the data point associated with specimen c144 for which the hold time is relatively short $(3,000$ seconds or approximately one hour) but cracking appeared to cease, i.e., reaching the constant load state.

Table 1. Summary of source data for Alloy UNS-N06022 SDFR model quantification.

\begin{tabular}{|c|c|c|c|c|}
\hline $\begin{array}{c}\text { Specime } \\
\mathrm{n}\end{array}$ & Hold time, hours & $\begin{array}{c}\text { Tested stress intensity factor, } \\
\mathrm{MPa}(\mathrm{m})^{1 / 2}\end{array}$ & $\begin{array}{c}\text { Measured Crack Growth Rate, } \\
\mathrm{mm} / \mathrm{s}\end{array}$ & $\begin{array}{c}\text { Calculated "n" value } \\
(\text { see Note 3) }\end{array}$ \\
\hline $\mathrm{c} 153$ & $\mathrm{CL}^{\text {Note }}$ & 30 & $2.50 \mathrm{E}-10$ & 1.1680 \\
\hline $\mathrm{c} 153$ & $\mathrm{CL}^{\text {Note } 1}$ & 30 & $5.00 \mathrm{E}-10$ & 1.1190 \\
\hline $\mathrm{c} 144$ & 1 & 30 & $1.00 \mathrm{E}-11^{\text {Note } 2}$ & 1.3910 \\
\hline $\mathrm{c} 152$ & 24 & 45 & $1.00 \mathrm{E}-11^{\text {Note } 2}$ & 1.5630 \\
\hline $\mathrm{c} 152$ & 24 & 45 & $4.00 \mathrm{E}-10$ & 1.2810 \\
\hline
\end{tabular}

Notes: $1 . \mathrm{CL}=$ Constant Load

2. Growth rate of 1.0E-11 is used for test results where either cracking appeared to cease or the growth rate seemed to arrest.

3. Each of the values in the column "Calculated "n" value" is calculated from Eq. 1.

Table 2. Distribution of the parameter "n"

It can be determined from the $\mathrm{n}$ values in the last column of Table 1 that the mean value of $n, n_{\text {MEAN }}$, is 1.304 and the standard deviation (SD), $\mathrm{n}_{\mathrm{SD}}$, is 0.160 . Based on these mean and standard deviation values, a normal distribution for " $n$ " can be constructed. The $\mathrm{n}$ values at various percentiles, truncated at \pm 2 (SD), are listed in Table 2 .

The base case slip dissolution/film rupture SCC model developed for Alloy UNS-N06022, represented by Eq. 1, is graphically illustrated in Fig. 4 for $n$ values at 0.984 (-2 standard deviation), 1.304 (mean), and 1.624 (+2 standard deviation), along with test data presented in Table 1 and the graphical representation of Eq. 1 for stainless steel (with $\mathrm{n}=0.54$ ). Excellent resistance to SCC for Alloy UNS N06022 is clearly illustrated in Fig. 4 where even the higher crack growth rates exhibited by the top curve of Alloy UNS N06022 with $\mathrm{n}=0.984$ ( -2 standard deviation) are about 2 orders of magnitude lower than the crack growth rates associated with the stainless steel curve.

\section{VALIDATION OF THE SDFR CRACK GROWTH MODEL}

For sensitized Type 304 stainless steel in $288^{\circ} \mathrm{C}$ water, Ford and Andresen (1988) indicate that Eq. 1 with $n=0.54$ is a good prediction model for observed crack growth rate vs. crack tip strain rate relationships. Further, this slip dissolution/film rupture model has been statistically validated for the chromium containting, nickel base Alloys 600 and 182 over a range of anionic impurity concentrations (Ford and Andresen 1988).

Subsequently, Andresen (1991) used the SDFR model for the higher chromium content nickel base alloy, Alloy 82 (UNS N06082, 18-22\% Cr), which overlaps Alloy UNS-N06022 $(20-22.5 \% \mathrm{Cr})$ in chromium content. Analyses indicate that the

\begin{tabular}{|c|c|}
\hline n-value & Percentile \\
\hline $0.984(-2$ SD) & 2.28 \\
\hline 1.041 & 5.00 \\
\hline 1.099 & 10.00 \\
\hline 1.139 & 15.00 \\
\hline $1.144(-1$ SD) & 15.87 \\
\hline 1.170 & 20.00 \\
\hline 1.221 & 30.00 \\
\hline 1.264 & 40.00 \\
\hline $1.304($ Mean) & 50.00 \\
\hline 1.345 & 60.00 \\
\hline 1.388 & 70.00 \\
\hline 1.439 & 80.00 \\
\hline $1.464(+1$ SD) & 84.13 \\
\hline 1.470 & 85.00 \\
\hline 1.509 & 90.00 \\
\hline 1.568 & 95.00 \\
\hline $1.624(+2$ SD) & 97.72 \\
\hline
\end{tabular}

inner, protective corrosion films that form in the passive potential range on such nickel base, chromium containing alloys with greater than about $15 \%$ chromium contain a very thin passive film layer of primarily $\mathrm{Cr}_{2} \mathrm{O}_{3}$ (with some nickel content) at the oxide/alloy interface (Pensado et al. 2002). Such a thin passive $\mathrm{Cr}_{2} \mathrm{O}_{3}$ film is likely to possess similar repassivation kinetics and mechanical properties, e.g., fracture strain, over the range of nickel-chromium base alloys of interest. This is consistent with the model having been shown to apply or to give reasonable predictive results for a range of nickel base alloys with chromium contents spanning the Alloy 22 compositional range. 
Crack growth rate for Alloy 22

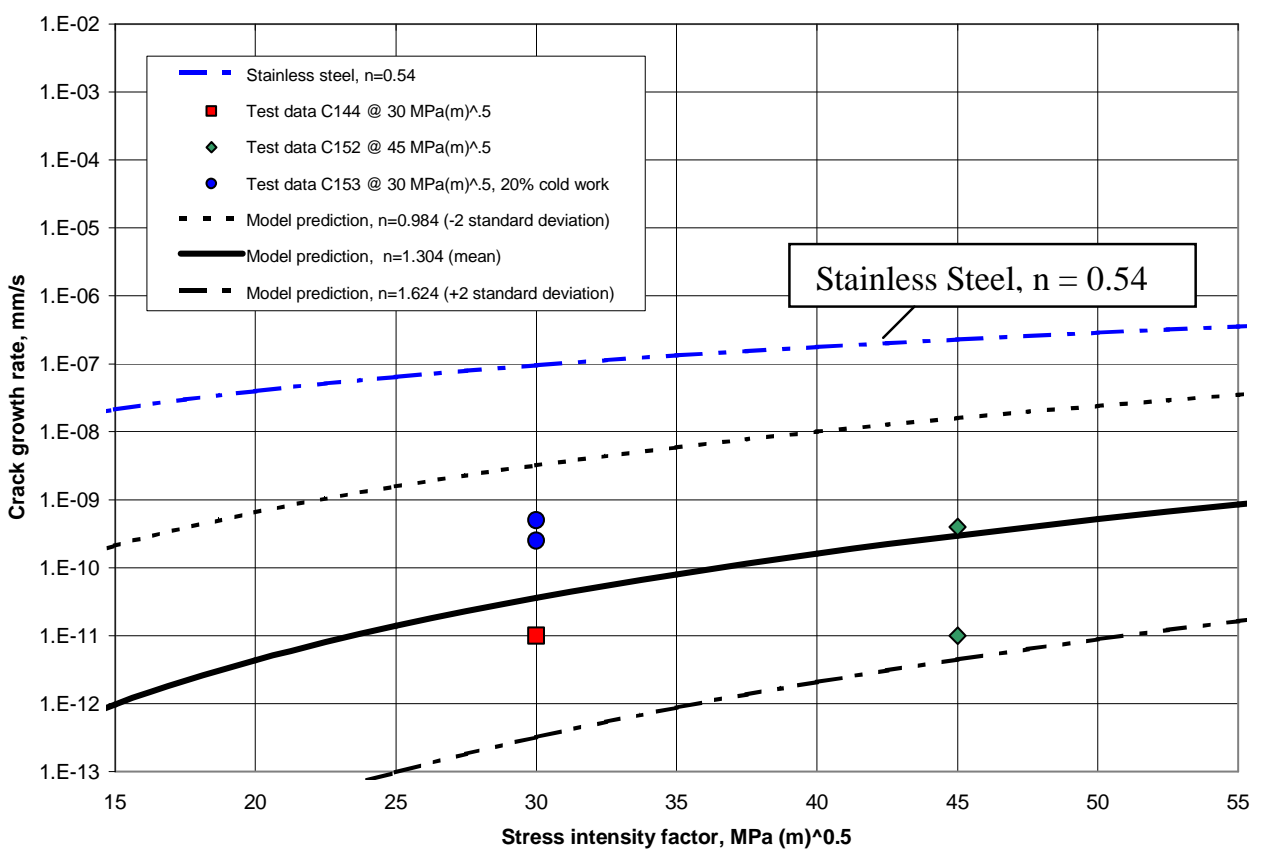

Fig. 4. Crack growth rate vs. stress intensity factor for Alloy UNS-N06022 based on the SDFR model.

Since the SDFR was initially developed for stainless steels and nickel-based alloys Inconel 600/182 under higher temperature $\left(\sim 288^{\circ} \mathrm{C}\right)$ light water reactor coolant conditions, additional confidence in the applicability of this model to Alloy UNS N06022 can be gained from observation of the response of Alloy UNS-N06022 under similar light water reactor coolant conditions. Recent test results performed at the GE Global Research Center (GEGRC) for the Yucca Mountain Program indicate the crack growth rate response of Alloy 22 exposed to $288^{\circ} \mathrm{C}$ relatively pure water $\left(2 \mathrm{ppm} \mathrm{O}_{2}\right)$ is broadly consistent with other materials, such as Alloys 600 and 182 (Andresen et al. 2002b) and austenitic stainless steel (Andresen et al. 2002a) under these same conditions. The test results at GEGRE were obtained for Alloy UNS-N06022 forged at room temperature to $21 \%$ reduction in thickness, fabricated to a $0.5 \mathrm{TCT}$ specimen, and assembled and tested using techniques identical to those describe in Andresen et al. (2003). The measured crack growth rates show a similar dependency to parameters like corrosion potential and water purity (sulfate). For example, in all test cases, the change in corrosion potential from $\sim+0.2 \mathrm{~V}_{\mathrm{SHE}}$ to $\sim-$ $0.5 \mathrm{~V}_{\mathrm{SHE}}$ (due to a change from $2 \mathrm{ppm}_{2}$ to $\mathrm{H}_{2}$-deaerated water) causes a drop of at least one order of magnitude in the crack growth rate, as indicated by Table 3. Also, as expected, Alloy UNS-N06022 shows crack growth rates under repository type oxidizing conditions, i.e., at $0.2 \mathrm{~V}_{\text {SHE }}$ which are about one order of magnitude lower than those of the other materials under identical test conditions, demonstrating its superiority as a structural material under conditions where stress corrosion cracking is a concern.

The good crack growth rate predictive capability of Eq. 1 (benchmarked with the experimental results, presented in Table 1) has been validated with a separate set of measured crack growth rates (see Table 4, column 4), which are plotted in Figure 5. This separate set of measured crack growth rates were collected using a method similar to the reversing direct current measurement technique with compact tension type fracture mechanics specimens employed at LLNL. As can be seen from Figure 5, there is good agreement between the LLNL data and the predictive curves and statistical limits based on the crack growth rate results summarized in Table 1. From Table 4, it can be seen that the prediction error ratio is in the range of -0.93 to 54.87. While the prediction error ratio is generally within the desired 2 orders of magnitude, the prediction model appears to have the tendency of over-prediction (with positive error ratio), i.e., on the conservative side, rather than under-prediction (with negative error ratio). Also, for specimen DCT-22, the measured growth rate is below the crack growth detection limit and thus the comparison between measured and predicted rates is not directly relevant. Furthermore, it can be seen from Figure 5 that measured data fall nicely between the two bounds representing 
two standard deviations of the mean value. The agreement between the prediction and measured data shown in Figure 5 provides important input to the validation of the SDFR model for Alloy UNS-N06022.

Table 3. Measured crack growth rates due to drop in corrosion potential

\begin{tabular}{|c|c|c|c|c|}
\hline Alloy & $\begin{array}{c}\text { Stress Intensity } \\
\text { Factor } \\
\mathrm{MPa}(\mathrm{m})^{0.5}\end{array}$ & $\begin{array}{c}\text { Corrosion Potential } \\
+0.2 \mathrm{~V}_{\text {SHE }}\end{array}$ & $\begin{array}{c}\text { Corrosion Potential } \\
-0.5 \mathrm{~V}_{\text {SHE }}\end{array}$ & Note \\
\hline Alloy 22 & $\begin{array}{c}27.5 \\
\left.\mathrm{ksi}(\mathrm{in})^{0.5}\right]\end{array}$ & $2.3 \times 10^{-8}$ & $4.0 \times 10^{-9}$ & Measured data at GEGRC \\
\hline Alloy 182 & 28.4 & $3.0 \times 10^{-7}$ & $6.0 \times 10^{-9}$ & Andresen et al. (2002b) \\
\hline Alloy 600 & 30.0 & $3.3 \times 10^{-7}$ & $3.7 \times 10^{-8}$ & Andresen et al. (2002b) \\
\hline $\begin{array}{c}\text { Unsensitized Type } \\
\text { 316L Stainless Steel }\end{array}$ & $\begin{array}{c}27.5 \\
\left.[25 \mathrm{ksi} \text { (in) })^{0.5}\right]\end{array}$ & $4.1 \times 10^{-7}$ & $>2.0 \times 10^{-8}$ & Andresen et al. (2002a) \\
\hline
\end{tabular}

Crack growth rate for Alloy 22

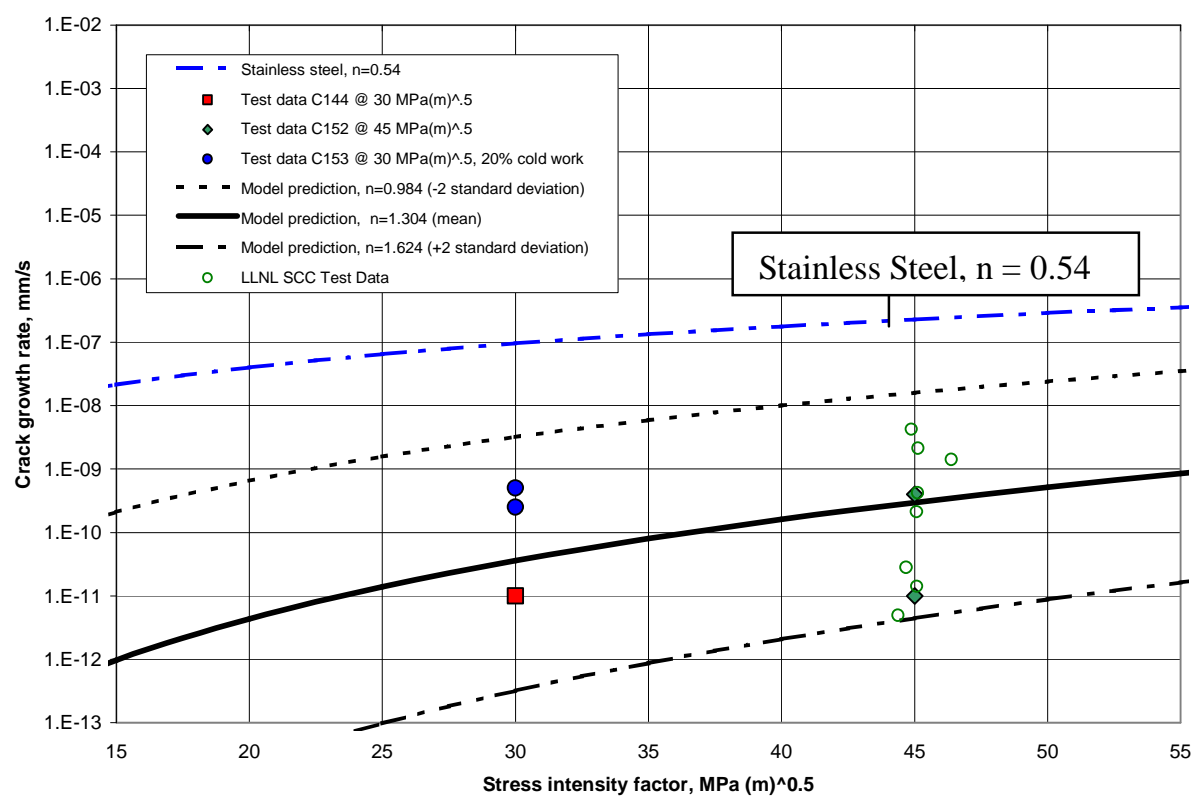

Fig. 5. Comparison of the SDFR prediction model and measured data for Alloy UNS-N06022 
Table 4. Comparison of Predicted and Measured Crack Growth Rates for Alloy UNS-N06022.

\begin{tabular}{|c|c|c|c|c|c|}
\hline $\begin{array}{c}\text { Specimen } \\
\text { ID }\end{array}$ & $\begin{array}{c}\text { Nominal } \\
\text { Test } \\
\text { Temperature } \\
\left({ }^{\circ} \mathrm{C}\right)\end{array}$ & $\begin{array}{c}\text { Average } \\
\text { Stress Intensity } \\
\mathrm{MPa}(\mathrm{m})^{0.5}\end{array}$ & $\begin{array}{c}\text { Measured } \\
\text { Crack } \\
\text { Growth } \\
\text { Rate } \\
(\mathrm{mm} / \mathrm{s})\end{array}$ & $\begin{array}{c}\text { Predicted } \\
\text { Crack } \\
\text { Growth } \\
\text { Rate } \\
(\mathrm{mm} / \mathrm{s})\end{array}$ & $\begin{array}{c}\text { Prediction } \\
\text { Error } \\
\text { Ratio }\end{array}$ \\
\hline DCT-13 & 100 & 45.13 & $2.12 \mathrm{E}-09$ & $3.02 \mathrm{E}-10$ & -0.86 \\
\hline DCT-14 & 100 & 44.88 & $4.23 \mathrm{E}-09$ & $2.93 \mathrm{E}-10$ & -0.93 \\
\hline DCT-16 & 100 & 46.38 & $1.41 \mathrm{E}-09$ & $3.48 \mathrm{E}-10$ & -0.75 \\
\hline DCT-18 & 94 & 45.07 & $2.12 \mathrm{E}-10$ & $3.00 \mathrm{E}-10$ & 0.42 \\
\hline DCT-19 & 94 & 45.08 & $1.41 \mathrm{E}-11$ & $3.00 \mathrm{E}-10$ & 20.28 \\
\hline DCT-20 & 95 & 45.11 & $4.23 \mathrm{E}-10$ & $3.01 \mathrm{E}-10$ & -0.29 \\
\hline DCT-21 & 95 & 44.68 & $2.82 \mathrm{E}-11$ & $2.87 \mathrm{E}-10$ & 9.18 \\
\hline DCT-22 & 95 & 44.37 & $4.94 \mathrm{E}-12$ & $2.76 \mathrm{E}-10$ & 54.87 \\
\hline
\end{tabular}

Notes: (1) Values in Column 6 are obtained from Eq. 1 with $\mathrm{n}=1.304$.

(2) Prediction error ratio $($ Col. 7$)=($ Col.. $5-$ Col. 6) $/$ Col. 5

\section{CONCLUSIONS}

This paper deals with the description and validation of the process-level model (see Fig. 2) developed for the performance assessment of the Alloy UNS-N06022 waste package outer barrier subjected to stress corrosion cracking due to weld induced stress in the final closure welds. The slip dissolution/film rupture model relates crack initiation and the subsequent advance to the metal oxidation that occurs when the protective film at the crack tip is ruptured.

Based on the discussion in this paper, the SDFR model with $\mathrm{n}=0.54$ is a good prediction model for sensitized Type 304 stainless steel in $288^{\circ} \mathrm{C}$ water. Further, it has been statistically validated for the chromium containting, nickel base Alloys 600 and 182 over a range of anionic impurity concentrations. Subsequently, it was used for the higher chromium content nickel base alloy, Alloy 82 (UNS N06082, $18-22 \% \mathrm{Cr}$ ), which overlaps Alloy UNS N06022 (20-22.5\% Cr) in chromium content.

Finally, the good crack growth rate predictive capability of Eq. 1 (benchmarked with the experimental results, presented in Table 1) has been validated with a separate set of crack growth rates measured at LLNL (see Table 4). As can be seen from Figure 5, there is good agreement between the LLNL data and the predictive curves and statistical limits. Fig 5 further indicates that measured data fall nicely between the two bounds representing two standard deviations of the mean value. The agreement between the prediction and measured data shown in Figure 5 provides important input to the validation of the SDFR model for Alloy UNS-N06022.
In conclusion, this paper has clearly demonstrated that the slip dissolution/film rupture model can be applied to assess the failure (or the lack of it) of the high level radioactive-waste packages due to SCC crack propagation for given manufacturing cracks and/or cracks initiated by the combined effects of stress and environment.

\section{ACKNOWLEDGMENTS}

This work was performed under the auspices of the U. S. Department of Energy by the University of California, Lawrence Livermore National Laboratory under Contract $\mathrm{N}^{\mathrm{o}}$ W-7405-Eng-48. This work is supported by the Yucca Mountain Project, LLNL.

\section{REFERENCES}

Andresen, P.L. 1991, "Fracture Mechanics Data and Modeling of Environmental Cracking of Nickel-Base Alloys in High Temperature Water," Paper No. 44, Corrosion 91, March 11-15, 1991, NACE.

Andresen, P.L., Angeliu, T.M., Young, L.M., Catlin, W.R., and Horn, R.M. 2002a, "Mechanisms and Kinetics of SCC in Stainless Steels," Tenth International Conference on Environmental Degradation of Materials in Nuclear Power Systems-Water Reactors, August 5 to 9, 2001, Lake Tahoe, Nevada. Houston, Texas: NACE International.

Andresen, P.L., Emigh, P.W., Young, L.M., and Gordon, G.M. 2003, "Stress Corrosion Cracking Growth Rate Behavior of Alloy 22 (UNS N06022) in Concentrated Groudwater," Corrosion 2003. The annual conference and corrosion show sponsored by NACE International. Paper No. 03683. 
Andresen, P.L. and Ford, F.L. 1988, "Life Prediction by Mechanistic Modeling and System Monitoring of Environmental Cracking of Iron and Nickel Alloys in Aqueous Systems," Materials Science and Engineering, A103, pp. 167-184.

Andresen, P.L., Young, L.M., Emigh, P.W., and Horn, R.M. 2002b, "Stress Corrosion Crack Growth Rate Behavior of Ni alloys 182 and 600 in High Temperature Water," Paper No. 02510, Corrosion 2002, NACE, March 2002.

ASM International. 1987, Corrosion. Volume 13 of Metals Handbook. 9th Edition.

BSC (Bechtel SAIC Company) 2001, Environment on the Surfaces of the Drip Shield and Waste Package Outer Barrier. ANL-EBS-MD-000001 REV 00 ICN 02. Bechtel SAIC Company, Las Vegas, Nevada.

BSC (Bechtel SAIC Company) 2003, Analysis of Mechanisms for Early Waste Package/Drip Shield Failure. CAL-EBS-MD-000030 REV 00. Bechtel SAIC Company, Las Vegas, Nevada.

CRWMS M\&O 1996, Waste Package Closure Weld Development Report. BBA000000-01717-2500-00006 REV 00. Civilian Radioactive Waste Management System (CRWMS) Management and Operation Contractor (M\&O), Las Vegas, Nevada.

DOE (U.S. Department of Energy) 2001, Yucca Mountain Science and Engineering Report. DOE/RW-0539. Washington, D.C.: U.S. Department of Energy, Office of Civilian Radioactive Waste Management. May 2001.
Ford, F.P. and Andresen, P.L. 1988, "Development and Use of a Predictive Model of Crack Propagation in 304/316L, A533B/A508 and Inconel 600/182 Alloys in $288^{\circ} \mathrm{C}$ Water," Environmental Degradation of Materials in Nuclear Power Systems-Water Reactors, [Proceedings of the Third International Symposium, Traverse City, Michigan, August 30September 3, 1987]. Theus, G.J. and Weeks, J.R., eds. Pages $798-800$.

Jones, R.H. and Ricker, R.E. 1987, "Stress-Corrosion Cracking," Metals Handbook Ninth Edition. Volume 13. Corrosion . pp. 145-163.

Lu, S.C., Gordon, G.M., Andresen, P.L., and Herrera, M.L. 2003, "Modeling of Stress Corrosion Cracking for High Level Radioactive-Waste Packages." Transportation, Storage, and Disposal of Radioactive Materials - 2003. PVP-Vol. 467. The American Society of Mechanical Engineering. New York, NY. pp. 119127.

Pensado, O., Dunn, D.S., Cragnolino, G.A., and Jain, V. 2002, Passive Dissolution of Container Materials-Modeling and Experiments. CNWRA 2003-01. San Antonio, Texas: Center for Nuclear Waste Regulatory Analyses.

Young, L.M., Catlin, G.M., Andresen, P.L., and Gordon, G.M. 2003, "Constant Load SCC of Proposed Waste Package Materials in Mixed Salt Solutions," Eleventh International Conference on Environmental Degradation of Materials in Nuclear Power Systems - Water Reactors, August 10-14, 2003, Stevenson, WA., American Nuclear Society Conference Proceedings, pp. 267-279. 